\title{
THE PROSPECT OF LEGAL EDUCATION: AN INDIA OVERVIEW
}

\section{Hari Hara Sudhan Ramaswamy"}

Tamil Nadu, India, E-mail: harihs.research@gmail.com

\section{(Received: February 2020; Accepted: April 2020; Published: June 2020)}

\begin{abstract}
Education in India is losing its relevance. This seems much more applicable to the situation in the present day of legal education. This essay aims to focus on two aspects of legal education. Whilst, on one hand, it aims to provide details of the existing legal education system on the other, it aims to drive more attention to the various improvements and developments that are needed. The essay firstly shall describe the existing legal education system. It shall analyze and assess the curricula that are available for the various undergraduate law degrees available in India. It aims to provide an understanding of the perceived distinctions between the three-year law degree and the five-year law degree. As a second aspect, the essay aims to explore options to further the quality of legal education in India by considering examples of various law schools or colleges of law across the world that have consistently proven themselves as a cut-above not legal education and research in their global scale. Also, from the learnings of the gaps in the curricula of the law degrees as discussed previously, the essay shall provide suggestions on the various plausible collaborations with foreign law schools and universities for the benefit of the Indian law schools and colleges of law. As a third and final aspect, as a measure to curb fake or bogus law schools or colleges of law within India and to enhance the employability of law graduates in India at par with those across the globe, the essay aims to provide suggestions applicable for the present-day legal education scenario.
\end{abstract}

Keywords: Legal Education, India, USA, Australia, Legal Studies.

\section{Introduction}

India's education system comes from the concept of 'Gurukul' and unarguably is home to the world's first-ever university - Nalanda University. Despite such benchmarks, Indian education seems to have become obsolete. This is evident as the reports by Xavier (2011) surfaced about the employability of the engineering and other graduates in India, according to which whilst seventy-five percent of India's

\footnotetext{
* Corresponding author: Hari Hara Sudhan Ramaswamy.E-mail: harihs.research@gmail.com
}

Copyright (c) 2020 The Author(s). Published by VGWU Press

This is an Open Access article distributed under the terms of the Creative Commons BY 4.0 license (Creative Commons - Attribution 4.0 International - CC BY 4.0) which permits unrestricted use, distribution, and reproduction in any medium, provided the original author and source are credited. 
Ramaswamy, H.H.S., (2020)

engineering graduates are unemployable, eighty-five percent of the graduates of other subjects or degrees are also unemployable of the three million graduates and post-graduates who add on to India's work-force each year.

This is particularly relevant in one of the most required professions in any country. Legal education in India was and to a large extent still continues to not be the most preferred field of academic pursuit for many students especially the ones with very high marks (Badrinarayana, 2014). It was only with the National Law School awareness and the career opportunities for law graduates began attracting students from across India. In addition to this, it is pertinent to note the reports stating that approximately one million two hundred thousand lawyers of the two million lawyers in the country being fake, as reported by Sarda (2017). This is the sort of level or state in which the legal education in India is currently held.

This piece works towards analyzing through the available literature and other secondary sources, the source of the planning and execution of legal education in India. It tries to understand how this source has executed legal education in their country. It compares the legal education in select countries such as the United States of America (U.S.A.,), and Australia and certain other off-beat countries such as in China and Brazil. The paper also analyses the various achievements and the other sign-ports in the sojourn of the establishment, planning, executing and the other procedures of legal education.

This paper looks briefly at the curricula which have been established for students intending to pursue a legal education in India. A consolidated approach is taken on the curricula available in all the educational institutions available which provide legal education. This consolidation is arrived at by initially comparing and contrasting the distinctions of legal education within India. As a further step, the curricula that are available at world-class institutions abroad are considered for comparison. It compared the curricula, suggestions are made on regularizing the curricula and of the existence of both the five-year dual-degree law programs and the three-year stand-alone law programs.

Upon comparison, as a measure to address the quality of legal education available at the various law-universities and law-colleges in India, the research capacity and the funding that is made available to the law-universities and law-colleges in India is addressed. This analysis of the quality of legal education is added by providing suggestions on the possible collaborations that could be reached by the internationalization activities of the various law-universities and law-colleges in India with those of international repute and excellence abroad.

Having made a mention about an alarming issue of fake-lawyers which deteriorate the quality of the legal education provided and learned and the incurable plague that this aspect may cause on the law-making in India and other legal and constitutional facets of the running of a nation are considered briefly. Further, as a concluding note,

32 Sciendo Journal of Legal Studies Volume 25 Issue 39/2020 ISSN 2457-9017; Online ISSN 2392-7054. 
Ramaswamy, H.H.S., (2020)

"Vasile Goldiş" Western University of Arad

The prospect of legal education: An India overview

suggestions are made upon comparison of the bar council mechanism in countries abroad to curb the increase of fake-lawyers.

\section{Understanding the history}

The concept of law in India dates back to the Vedic period in line with such ancientIndia concepts as Dharma - an inherent concept of the Hindu religion. This could be understood from the writings of the Manu Smriti. In such a time there was no proper formal legal education installed to teach the law. However, concepts such as Karma and Dharma governed people, their thoughts and actions. Justice was administered either by the kings themselves or by those appointed as judges by the king. The judges also would not have had proper training in carrying out the justice however would have been people who were just and righteous.

Whilst the aforementioned was ancient history it had a difference in the colonial era starting with the Mughal era. During this time the emperor would be the head of the judiciary. It was during this period where clear demarcations began between civil, criminal, family and other codes of law which in turn paved the way to the need of people who are experts in these branches of the law. It is pertinent to note that these branches of law were at the time much in line with the Quran although the villagelevel disputes employed the Hindu-law. Also, during this time in villages, the panchayats played a key role in executing justice.

Following the aforementioned ancient and Mughal eras is the British period. The present-day legal education in India has received much of its contribution from the British imperial rule in India during which time, proper structuring of the establishment of law was made by the installation of Courts of law in Madras (erstwhile Chennai), Bombay (erstwhile Mumbai) and Calcutta (erstwhile Kolkata). However, there was a dire need of law practitioners in India with the establishment of the Supreme Court in Calcutta in 1774. To address this growing issue, as a first in northern-India, legal education was commenced in the province of Punjab in 1868. As continuation police personnel in Travancore received training in law in vernacular languages in 1874 which further led to the establishment of academic institutions for the purposes of legal education in other parts of India. After the Independence of India, there was an establishment of many more academic institutions for legal education. However, most of these did not have the most basic of the amenities in terms of infrastructure such as a library, proper class-rooms, etc., These academic institutions also did not meet the standards to be declared as universities.

After the independence of India, upon several high-level deliberations, a Bar Council of India was founded along with the various State-level Bar Councils. Such a council headed by the Judge of the Supreme Court of India was formed owing to the recommendations which came from the deliberations of the various committees to

sciendo Journal of Legal Studies Volume 25 Issue 39/2020 
Ramaswamy, H.H.S., (2020)

The prospect of legal education: An India overview

monitor the quality of legal education in a uniform manner. The Bar Council of India and the other State Bar Councils shall act as the apex bodies and shall be able to implement the recommendations as highlighted by the Bar Councils due to the comprehensive Advocates Act, 1961 as enacted by the Parliament of India.

\section{The present story}

With the many law colleges instituted in India after independence, owing to the importance of the study of law and the role it plays in nation-building, a lot of interest was shown corresponding to the number of law colleges that sprouted then. It was imperative to maintain the quality and structure of legal education. However, this was out of hand. It was only when the National Law School of India University (NLSIU) in Bengaluru in 1986, did legal education become a highly in-demand field of study. India had to look at many other countries including the United States for guidance in forming a structure in the selection of students who would take up legal education.

Prior to this, the student quality was considered as being extremely low which again affects the quality of legal education, the graduate outcomes, the quality of academicians in the legal fraternity, the quality of lawyers, etc., The United States had the Law Schools Aptitude Test (LSAT) much before as a mechanism in place to select students to pursue a legal education. However even in 1986, as opined by Getman (1969), this was by and large absent in India letting the profession and its outcome suffer a plague.

It is an inarguable fact that students' interest was much towards Engineering and Medicine in India for a long time as opposed to a very less interest shown towards legal education. With the level of their learning capacity, the practicing lawyers were often categorized according to the training-level they had received. According to Dasgupta (2010), law schools in India were in such a way that the classes were being held in the evenings or the night time and it was seen that the students receive employment opportunities to work by the day.

This meant that the classes were mostly held on a part-time basis and the professors were also employed part-time which helped law schools save money. The law schools did not attract very high-profile professors due to the part-time and the meager-paying nature of the job. In addition to this, there was also no active and genuine interest and seriousness in teaching law.

\section{Three-years or five-years?}

India's legal education system provides two degrees. First is the traditional one for the fresh pass-outs from higher secondary which is a combination of two degrees having a Bachelor of Arts (B.A.) degree in addition to the Bachelor of Laws which was abbreviated at B.L. at the time. The second was the three-year degree which is

34 sciendo Journal of Legal Studies Volume 25 Issue 39/2020 ISSN 2457-9017; Online ISSN 2392-7054. 
Ramaswamy, H.H.S., (2020)

The prospect of legal education: An India overview

offered for students who already hold a Bachelor's degree which is offered at an undergraduate-level. In countries like the United States students take up legal education at the post-graduate level professional-degree and the degree is often three-years only.

This means the students in the United States who take up legal education are required to have completed their four-year undergraduate degree prior to embarking on to the law degree. It should be noted that in Independent India, there was a two-year law degree that later underwent a reform under the leadership of Dr. S. Radhakrishnan, India's second President. Further, India had many law schools or law colleges which were both standalone with an affiliation to large universities and as departments of larger universities (Dasgupta, 2010). In both cases, it is required that the institutions have ample academic and research facilities.

Considering the academic and research facilities of the law schools in the West, India still has a far place to go. There is often in law colleges in India, not much seriousness and professionalism offered towards students pursuing a three-year law degree. This is especially the case with many privately-held academic institutions that provide legal education. Their stand-point is perhaps due to the cost being borne by the fiveyear law degree students which is higher in comparison with the three-year law degree students.

In addition to the aforementioned reason, it is evident that the three-year law degrees are not taken up and provided at the various publicly-funded National Law Schools of India including the National Law School of India University (NLSIU) in Bengaluru and the NALSAR University in Hyderabad. This indicates that the threeyear law degrees have been left for as a playground for certain privately-held institutions providing legal education to sustain in business due to which many operate on the basis of high fees for all its degrees and lesser academic standards when compared to the NLSIU or the NALSAR.

This sort of distinction between the five-year law degree and the three-year law degree assumes a position that students intending to pursue legal education are required to have finalized their interest whilst pursuing their higher secondary. The legal education fraternity considers these students as the most relevant crowd to undergo legal education. These results in people who may want to study a three-year law degree after perhaps the completion of a first-degree not having the opportunity to do so at a decent institution that would concentrate on academic, teaching and research excellence.

Also, the disinterest of National Law Schools in India to offer the three-year law degrees for graduates has resulted in that private law schools can offer these to such students whoever provides the fee required. This indicates that there can be a very high probability of a compromise on the quality of students who are provided with the admission to private law schools to pursue a three-year law degree. Many if not 
Ramaswamy, H.H.S., (2020)

all of these private law schools do not conduct any entrance tests for the students intending to pursue the three-year Bachelor of Laws.

The national level entrance exams such as the Common Law Aptitude Test (CLAT) and the Law School Aptitude Test (LSAT) are usually for the students who intend to study the five-year law degrees who have just passed out of their higher secondary examinations. This distinction between the admission mechanism between the fiveyear degree program and the three-year degree program does not ensure the quality of law graduates and law professionals. This should be addressed for being a serious folly.

Although the purpose of the five-year program is for recent students who have passed-out of higher secondary examinations and the three-year program for students who already possess a Bachelor's degree, the present scenario dictates another situation at hand, whereby the law schools offering the three-year course seem to attract students of very low caliber and go-on to affect the practical aspects of having obtained a law degree.

The initially quoted number on the 'fake' lawyers in India who constitute more than half the total number is an evident example of the state of the enrolments that the legal profession seems to have and is also indicative of the quality of law graduates who are churned-out every year adding on to the scene of unemployment each year (Sarda, 2017). This adds-on to the existing number of graduates who are unemployed due to their employability gaps. This is a sadder state for the law graduates to face unemployment due to the superior nature of the subject. Also, being a professional degree, although one is able to establish a private practice, that try could be a toll for the fresh law graduates especially when there is a serious lack in the quality of education they have received.

\section{Exploring abroad}

India has been subjected to many foreign invasions be it during the Mughal era or even during the British colonial era. Much of what the people of India enjoy now are the remains from their rule. Due to a large portion of India's population being uneducated, it was a trend of the pre- and post-independence policy-makers was to take reference to the developments of policies abroad and to customize it according to the Indian people and implement the same in India. India is known to have taken as an example the systems in place in such countries as the United States, United Kingdom, Australia and certain others to be able to augment the quality of education in India.

Considering the example of the United States, it is imperative to note that the legal education provided in the country has sprung with the ideology of the Jeffersonian Vision of Legal Education in the early 1780s Douglas (2001). According to Douglas, Thomas Jefferson provides the legal professionals of the United States a rather

36 sciendo Journal of Legal Studies Volume 25 Issue 39/2020 
"sophisticated" role to uphold the country's republication form of government (p. 185). In his view, the provision of legal education in colonial America was not an effective method of learning and indicated specialized learning spaces for law than even in university settings.

Aspiring lawyers in colonial America did not have many opportunities in comparison to their British counterparts. The type of legal education which these lawyers received did not provide them with the necessary knowledge and training. Often, one of the modes these lawyers in colonial America had to adopt to get trained in law is by self-study. However, it was an expensive practice as the text-books were very expensive. Public libraries were out of the question and reach then. Without practical training to understand these law books were proving to be difficult.

Although the lawyers of the colonial America had no importance and much role to play then, this changed after the independence. In the independent America the concept of 'public good' dominated all decisions and actions and the lawyers at the time were regarded as such people who could work for the public good in the independent America. During this time the structure of the government and certain colleges changed to facilitate the provision of legal education by decreasing the role of the Church and the Crown in the decisions being made. Amidst these efforts, it is pertinent to note that the College of William and Mary in Virginia, United States of America became the first college to provide formal university-level legal training in 1780 (Strickland, 2001).

Since this time, much has been changing in the way legal education was provided in the United States. In 1890 for example, not many law schools had entrance examinations in the United States which made it easier to gain entry into a law school than to an Arts and Sciences degree. There had been times when law schools admitted every other applicant. Further, the 1970s saw a huge hike in the number of applicants applying to study law at the law schools. The influx of applicants was from varied backgrounds which increased competition.

The present scenario of the US legal education is that there are two types of degrees available for students wishing to pursue legal education in the United States. One is the traditional Bachelor of Laws alongside another Bachelor's degree which constitutes a five-year degree. The other is a three-year graduate-law degree for students coming from a non-law background - Juris Doctor (JD) - which is offered at the post-graduate level. Both of these require an entrance exam clearance viz. the Law School Aptitude Test (LSAT).

Many law schools in the USA are now shifting towards offering only a JD rather than the five-year program. Data from the American Bar Association (ABA) states that there are 110,156 current enrolments to the JD degree program in 2017 as opposed to 110,951 enrolments in 2016. There are currently 205 law schools across 
Ramaswamy, H.H.S., (2020)

"Vasile Goldiş" Western University of Arad

The prospect of legal education: An India overview

the USA which are approved by the ABA and there are several more to be (American Bar Website, 2017).

The legal education scenario in Australia is quite similar to that of the USA and both the countries' goal is to impart the best possible legal education to its students and to help them deliver the best practices in the legal profession, although the term 'best' is often contested in within and between each country. In Australia, clinical legal education, a form of legal training, which involves students playing the roles of reallawyers to real clients is given a lot of importance to. Whilst this is in Australia, some countries may choose to give importance to the theoretical legal knowledge (Evans, Cody, Copeland, Giddings, Noone \& Rice, 2017).

The similarities between the Australian and the US legal education system is also exhibited in the recent trend and shift in Australia towards the adoption of JD degree at many of the Australian universities which house world-class and infamous publicly-funded law schools viz. the Melbourne Law School which is a part of the University of Melbourne, the Sydney Law School which is a part of the University of Sydney and Monash Law School which is a part of Monash University. Other law schools which have taken this route belong to the Australian National University (ANU), the University of New South Wales (UNSW), the University of Technology Sydney (UTS), Macquarie University and the University of Western Australia (UWA), to name a few (Study In Australia website, 2017).

Although the aforementioned Australian universities have taken the route of the many American universities in adopting the JD degree still there are two pending aspects:

1) Not all Australian universities have adopted to providing Juris Doctor (JD) degree; and

2) Not all Australian universities which have adopted to providing the JD have chosen an entrance examination viz. the Law School Aptitude Test (LSAT) the same as in the USA.

This could be a tactic for the universities to attract more students especially the students from abroad who wish to study a JD degree in Australia to be able to easily enroll in the degree. It is to be noted that the JD being a three-year long degree attracts a very huge fee in Australia especially so for the international students who often have not many scholarships as in the USA.

Considering the example of one of the BRICS (Brazil, Russia, India, China and South Africa) partner countries - Brazil - could prove imperative to be able to initiate better understanding, appreciation and a usage of the understanding and the appreciation to forge collaborations between the countries to strengthen the BRICS relationship further. Brazil's legal system is largely civil in nature meaning that the Courts do not enforce or make laws but only interprets the same for the legislators

38 sciendo Journal of Legal Studies Volume 25 Issue 39/2020 ISSN 2457-9017; Online ISSN 2392-7054.

Web: publicatii.uvvg.ro/index.php/jls. Pages $31-43$ 
Ramaswamy, H.H.S., (2020)

The prospect of legal education: An India overview

at the various levels to enact the same. This is due to the influence of Germany and Italy (De Araujo, 2001).

The law schools in Brazil are traditionally housed in the universities and are a part of an accreditation process of the Ministry of Education which is empowered to regulate the curriculum and other structures according to the need and demand. At the time of independence from Portugal Brazil's legal education attracted the elite and legal education was a number of changes was made before it could attract people of all social strata preparing law graduates for both public offices and private practice (De Araujo, 2001).

China is yet another BRICS partner with India with a significant history in its laws, rules and regulations. China practiced an age-old feudal law since at least 211 B.C. and a sudden opening up of the country to the Western ways forced it to practice foreign law. The country introduced Common Law in its curricula and it was becoming difficult due to the language barrier. Japan was the trusted bridge then bridging the language gap due to which many Chinese students studied Common Law in Japan (Wang, 2002).

China was forced to open-up its modern law schools which taught Common Law. The first of the law schools in China was established in Tianjin in 1895. These law schools hired many law professors from abroad who also knew Chinese. Soochow University law school was one such law school that taught its courses entirely in English. Slowly other law courses from other jurisdictions such as French law, etc. also made its way into the Chinese curriculum. However Chinese legal system, in general, was rooted in the European Continental Law and it hence China as is Taiwan perceived as a country practicing civil-law mostly.

China has at least ten different law degree types unlike in the United States (Wang, 2002). They are as follows:

- A two-year or three-year Associate Law degree program for the schoolleavers;

- A two-year Bachelor of Laws degree program for the people with the Associate Law degree;

- A four-year Bachelor of Laws degree which is rather a combination of the above two;

- A two-year Bachelor of Laws degree for non-law graduates;

- A five-year or six-year Dual-degree program;

- Two-year or three-year Juris Master degree (J.M.) originally adopted from the American Juris Doctor (JD) degree;

- A three-year Master of Laws (LL.M.) degree for the law graduates;

- A three-year Doctor of Philosophy (Ph.D.) degree which is similar to the S.J.D degree in the United States;

- A two-year post-doctoral law degree for Ph.D. holders; 
Ramaswamy, H.H.S., (2020)

The prospect of legal education: An India overview

China has far too many options that allow one to practice law in China. Also, one does not have to have a Master of Laws degree or a Ph.D. degree to qualify the bar exam. This is because any person in China is able to apply for the bar clearance provided, they have acquired a good level of legal knowledge even through selfdirective learning. The other drawbacks in Chinese legal education. It is far theoretical and not much practical.

\section{The curriculum}

The legal curriculum is supposed to be a practical affair. As evidenced in the examples of the countries as mentioned above the advanced countries like the United States and Australia follow a rigorous clinical legal education. This is a form of legal education which involves first-hand practical knowledge of the law students to gain the best of their legal acumen in place. For example, law students are placed in legal clinics and are often allowed to play the role of an actual lawyer for real clients and represent these real clients in the Courts of Law in the real cases.

Many universities in Australia like the University of New South Wales (UNSW), the University of South Australia and the University of Newcastle have their own legal clinics on-campus for their students to indulge in clinical training. This ensures a constant opportunity for the students of these universities to participate in clinical legal education. This form of legal education having an in-house legal clinic is characteristic of the United States legal education system (Evans et al., 2017).

Similarly, the other modes of legal education include external legal clinics and Australian universities such as Monash, La Trobe, Griffith and Murdoch Universities and the Australian National University (ANU) all involve its students with external legal clinics allow them practical exposure in this manner as well. This practice is not new and has been in practice at these universities for many decades now.

Many countries including the United States, United Kingdom, and Australia offer externships to its students. Externships include internships and placements to all the students who are enrolled. Students are often provided opportunities to intern with the finest law practitioners in the country and some get to practice with the international organization and intergovernmental organizations like the International Criminal Court (ICC), European Court of Justice (ECJ), the World Bank, Amnesty International and the like.

\section{Global legal learning}

A very common feature amongst the four countries quoted above - the United States, Australia, China and Brazil - have a well-structured legal education with a wide coverage of linkages and collaborations for research and other academic purposes with law schools and universities abroad. For example, China plays host to an LL.M. program in collaboration between one of its universities and Temple

40 sciendo Journal of Legal Studies Volume 25 Issue 39/2020 ISSN 2457-9017; Online ISSN 2392-7054. 
Ramaswamy, H.H.S., (2020)

The prospect of legal education: An India overview

University of the United States. This course is approved by the American Bar Association and the Ministry of Education in China. There are now many other universities trying to follow this model to attract foreign and in-country lawyers.

Hence, in this globalized world which is often offered to us as a global village, an increased international collaboration through positive understanding and mutual benefit is always in order. India in this way has a lot to learn. Where China has boldly sent its students to Japan to study Common Law despite being a Communist nation, India despite being globalized and democratic is still seen as taking very slow steps towards establishing itself as a hub of transnational education despite the major advantage that much of India speaks English in comparison with China or even Japan.

Australian law schools like the University of New South Wales (UNSW) Law School, Monash Law School of Monash University, Sydney Law School of the University of Sydney, University of Adelaide Law School, the Australian National University (ANU) Law School are amongst the world-renowned to have transnational partnerships with other globally renowned law schools such as in the National University of Singapore (NUS), the University of Oxford, the Washington College of Law, the University of Warwick, the University of Mannheim and the like. However, India is still playing a primitive role in this aspect.

\section{Curbing the fake ones}

To stop the fake law schools in India is paramount which will eventuate in increasing the number of good lawyers who would work with integrity and ethics towards nation-building. This means all the subjects and degrees offered at the various law schools and colleges must be accredited and reaccredited by the Bar Council of India from time to time and there should be an increased monitoring by the Ministry of Human Resource Development (MHRD) in India. As a further measure all law graduates should be accredited by the Bar Council of India.

There should be three-year law degree courses at all academic institutions making it vitally accessible to study and obtain a law degree by all people. These should be particularly monitored that there is a nominal fee and there is an entrance exam for the three-year law degrees. All national law schools should be encouraged to offer a Juris Doctor degree with an entrance exam to ensure quality students.

\section{Conclusion}

The lawyers and the judicial members form the most paramount backbone of any nation. India has witnessed many of these legal scholars and others who have extensively participated in the shaping of a large democracy such as India, be it whether reinforcing criminal laws, determining the dynamics of such institutions as family and also being such stalwarts who affect the making of the Constitution of 
Ramaswamy, H.H.S., (2020)

India as in any other country. This indicates the amount of burden which these experts saddle along with their entire life with.

The burden borne by the legalists means that they are to have a great deal of responsibility meaning that they are expected to have superior knowledge, experience, attitudes and most of all ethics and such attributes as professionalism. To achieve such qualities the legal education that the future legal experts have access to, ought to be of global competence especially in the increasingly globalizing world where competition is so high.

India which produces one of the highest numbers of graduates should aim to have high-quality legal education graduates with critical thought and a broad-mind with legal ethics and integrity embedded in their curriculum and beyond. This could be afforded primarily by achieving constant updates and amendments in the curricula at the various academic institutions which disseminate legal knowledge and confer degrees.

Apart from the curricular updates, the universities, colleges and institutes in India which teach taught and research degrees in law must ensure that they increase their visibility, participate in the various independent ranking systems in India and abroad, invest on legal research and also importantly advertise so that institutions, as suggested above, are able to seek and are welcome to seek academic collaborations. As a conclusion, these suggestions could be expected to help in the improved provision of legal scholarship which can most definitely be expected to help law students to hone their skills so that the country could welcome better qualified and skilled legal scholars and experts to serve not only India but also the countries across the world in this extremely globalized world wherein borders keep disintegrating and irrelevant.

\section{Acknowledgments}

The author thanks the anonymous reviewers and editor for their valuable contribution.

\section{Funding}

This research received no specific grant from any funding agency in the public, commercial, or not - for - profit sectors.

\section{Author Contributions}

The entire article was written by Hari Hara Sudhan Ramaswamy.

\section{Disclosure Statement}

The author has not any competing financial, professional, or personal interests from other parties.

42 sciendo Journal of Legal Studies Volume 25 Issue 39/2020 
Ramaswamy, H.H.S., (2020)

"Vasile Goldiş" Western University of Arad

The prospect of legal education: An India overview

\section{References}

1. Badrinarayana, D. (2014). India's State of Legal Education: The Road from NLSIU to Jindal. Journal of Legal Education, 63(3), 521-523. Retrieved March 24, 2020, from www.jstor.org/stable/42898396.

2. Dasgupta, L. (2010). Reforming Indian Legal Education: Linking Research and Teaching. Journal of Legal Education, 59(3), 432-449. Retrieved March 24, 2020, from www.jstor.org/stable/42894129.

3. De Araujo, N. (2001). The Status of Brazilian Legal Education. Journal of Legal Education, 51(3), 325-331. Retrieved March 24, 2020, from www.jstor.org/stable/42893700. 4. Douglas, D. (2001). The Jeffersonian Vision of Legal Education. Journal of Legal Education, 51(2), 185-211. Retrieved March 24, 2020, from www.jstor.org/stable/42893690. 5. EVANS, A., CODY, A., COPELAND, A., GIDDINGS, J., JOY, P., NOONE, M., \& RICE, S. (2017). Clinics and Australian law schools approaching 2020. In Australian Clinical Legal Education: Designing and operating a best practice clinical program in an Australian law school (pp. 11-38). Acton ACT, Australia: ANU Press. Retrieved March 24, 2020, from www.jstor.org/stable/j.ctt1q1crv4.7.

6. EVANS, A., CODY, A., COPELAND, A., GIDDINGS, J., JOY, P., NOONE, M., \& RICE, S. (2017). Australian best practices-a comparison with the United Kingdom and the United States. In Australian Clinical Legal Education: Designing and operating a best practice clinical program in an Australian law school (pp. 219-240). Acton ACT, Australia: ANU Press. Retrieved March 24, 2020, from www.jstor.org/stable/j.ctt1q1crv4.15.

7. Getman, J. (1969). THE DEVELOPMENT OF INDIAN LEGAL EDUCATION: THE IMPACT OF THE LANGUAGE PROBLEM. Journal of Legal Education, 21(5), 513-522. Retrieved March 24, 2020, from www.jstor.org/stable/42891995.

8. Sarda, K. (2017). 12 lakh fake lawyers plague India's courts, The New Indian Express, $\begin{array}{lllll}\text { February } & 5017 . & \text { Retrieved }\end{array}$ http://www.newindianexpress.com/thesundaystandard/2017/feb/05/12-lakh-fake-lawyersplague-indias-court-1567019.amp.

9. Strickland, R. (2001). Creating Opportunity: Admissions in U.S. Legal Education. Journal of Legal Education, 51(3), 418-422. Retrieved March 24, 2020, from www.jstor.org/stable/42893715.

10. Wang, Z. (2002). Legal Education in Contemporary China. The International Lawyer, 36(4), 1203-1212. Retrieved March 24, 2020, from www.jstor.org/stable/40707710.

11. Xavier, D. (2011). 85 percent graduates in India not employable, Rediff Get Ahead (Aug. 29, 2011 at 08:37 am), http://m.rediff.com/getahead/slide-show/slide-show-1-career-85percent-of-graduates-in-india-not-employable/20110829.htm.

12. www.studyinaustralia.gov.au (retrieved on 31st Dec 2017).

13.www.americanbar.org/groups/legal_education/resources/aba_approved_law_schools.ht $\mathrm{m}$ (accessed on 31st Dec 2017). 